Mateusz Grześków*

ORCID: 0000-0003-1011-6413

Uniwersytet Jagielloński

DOI: $10.19195 / 1733-5779.24 .2$

\title{
Pośrednie umieszczenie nazwiska komandytariusza w firmie spółki komandytowej w świetle art. 104 § 4 k.s.h.
}

\section{JEL Classification: K22}

Słowa kluczowe: firma, spółka komandytowa, komandytariusz, odpowiedzialność za zobowiązania spółki, nazwisko

Keywords: business name, limited liability partnership, limited partner, liability for company's obligations, surname

Abstrakt: W przypadku spółki komandytowej, której komplementariuszem jest podmiot niebędący osobą fizyczną, może mieć miejsce przypadek pośredniego umieszczenia nazwiska komandytariusza w firmie spółki, w sytuacji gdy w firmie komplementariusza umieszczone jest nazwisko komandytariusza. Obowiązek inkorporowania tej firmy do firmy spółki komandytowej wynika wprost z art. $104 \S 3$ k.s.h. W rezultacie dochodzi do kolizji z normą zawartą w art. 104 $\S 4$ k.s.h., zakazującą umieszczania nazwiska komandytariusza w firmie spółki komandytowej. Wymaga to podjęcia rozważań w drodze wykładni literalnej oraz funkcjonalnej, czy rzeczywiście dochodzi do naruszenia zakazu wyrażonego w art. $104 \S 4$ k.s.h. W konkluzji przyjmuje się, iż zasadne jest odrzucenie rygorystycznego podejścia wypływającego z interpretacji literalnej ze względu na potrzeby obrotu gospodarczego, zważywszy, iż do naruszenia zakazu dochodzi przede wszystkim z racji wypełnienia innej normy o charakterze ius cogens. W efekcie pośrednie umieszczenie nazwiska komandytariusza w firmie spółki komandytowej nie wiąże się ze zniesieniem ograniczonej odpowiedzialności komandytariusza za zobowiązania spółki wobec jej wierzycieli.

\section{The indirect placement of a limited partner's surname in business name of a limited liability partnership}

Abstract: In the limited liability partnership, whose general partner is a non-natural person, there is a possibility that in its business name may occur an indirect placement of a limited partner's

* Opiekun naukowy (Scientific Tutor) - Andrzej Szumański 
surname when general partner's business name contains surname of a limited partner. Accordance to art. $104 \S 3$ of Polish Code of Commercial Companies (CCC) limited liability partnership's business name shall contain full business name of at least one of its general partners who are non-natural persons. In the result art. $104 \S 4$ CCC is infringed by the force of the law itself. This conflict of laws can be resolved by application of either lingual or functional interpretations of these contracting to each other provisions. Due to the needs of business practice, more liberal approach to the application of art. $104 \S 4$ should be adopted. Additionally, it would be wrong to punish entities who are acting in accordance with law for obeying it. Finally, the indirect placement of a limited partner's surname in the business name of a limited liability partnership shall not result in holding limited partner liable for its debts.

\section{Wprowadzenie}

Niniejszy artykuł jest poświęcony kwestiom konsekwencji prawnych pośredniego umieszczenia nazwiska komandytariusza w firmie spółki komandytowej na gruncie regulacji zawartej w art. $104 \S 4$ Kodeksu spółek handlowych ${ }^{1}$. Poczynione w tym opracowaniu rozważania mają także zastosowanie do spółki komandytowo-akcyjnej ze względu na tożsamość regulacji zawartej w przepisie $127 \S 4$ k.s.h.

Problematyka dopuszczalnego oraz poprawnego konstruowania firmy spółki komandytowej stanowi przedmiot licznych opracowań w literaturze przedmiotu ${ }^{2}$ $\mathrm{z}$ uwagi na występujące $\mathrm{w}$ tym obszarze rozliczne wątpliwości doktrynalne oraz praktyczne. Zagadnienia te zatem nie będą $\mathrm{w}$ niniejszym artykule poruszane, gdyż jego celem jest skupienie uwagi na jednym określonym przypadku, który zasadniczo - jak dotąd - nie doczekał się szerszych opracowań ${ }^{3}$, tj. problematyce umieszczenia nazwiska komandytariusza w firmie spółki komandytowej. Ów przypadek sprowadza się do sytuacji, gdy nazwisko komandytariusza pojawia się w firmie spółki, ponieważ stanowi ono część korpusu firmy innego podmiotu niebędącego osobą fizyczną, a zatem obligatoryjne jest jego umieszczenie w firmie spółki komandytowej ze względu na ustawowy wymóg określony w art. 104

\footnotetext{
${ }^{1}$ Ustawa z dnia 15 września 2000 roku - Kodeks spółek handlowych (tekst jedn. Dz.U. z 2000 r. Nr 94, poz. 1037 ze zm.), dalej: k.s.h.

2 Por. przykładowo: M. Spyra, [w:] Kodeks spółek handlowych. Komentarz, red. J. Bieniak et al., Warszawa 2017, s. 328-337; T. Szczurkowski, [w:] Kodeks spótek handlowych. Komentarz, red. Z. Jara, Warszawa 2017, s. 371-376; A.J. Witosz, [w:] Kodeks spótek handlowych, t. 1. Komentarz do art. 1-150, red. A. Kidyba, Warszawa 2017, s. 689-704; M. Rodzynkiewicz, Kodeks spótek handlowych. Komentarz, Warszawa 2012, s. 163-166; P. Pinior, [w:] Kodeks spólek handlowych. Komentarz, red. J.A. Strzępka, Warszawa 2012, s. 176-180; J. Szwaja, I.B. Mika, [w:] Kodeks spótek handlowych, t. 1. Przepisy ogólne. Spótki osobowe. Komentarz do artykułów 1-150, red. S. Sołtysiński et al., Warszawa 2012, s. 839-848; P. Hajdys, Firma spótki osobowej - uwagi de lege lata i postulaty de lege ferenda, $\mathrm{PPH}$ 2012, nr 10; T. Siemiątkowski, [w:] Kodeks spótek handlowych. Komentarz. Tytuł I. Przepisy ogólne. Tytut. II. Spółki osobowe, t. 1, red. R. Potrzeszcz, T. Siemiątkowski, LEX/el. 2010, komentarz do art. 104.

3 Zob. P. Pinior, op. cit., s. 180; A.J. Witosz, op. cit., s. 698.
} 
$\S 3$ k.s.h., nakazujący umieścić w niej pełne brzmienie firmy (nazwy) osoby prawnej będącej komplementariuszem spółki. $Z$ tego powodu owa problematyka w niniejszym artykule została określona mianem pośredniego umieszczenia nazwiska komandytariusza w firmie spółki komandytowej. Zważywszy, iż w obrocie spotykane są podmioty o tak skonstruowanej firmie, rodzi to pytania o dopuszczalność jej rejestracji przez sąd rejestrowy oraz o konsekwencje prawne dla komandytariusza, wynikające z normy zawartej w art. $104 \S 4$ k.s.h.

\section{Istota regulacji art. $104 \S 4$ k.s.h.}

Celem regulacji zawartej w art. $104 \S 4$ k.s.h. jest ochrona wierzycieli spółki komandytowej ${ }^{4}$. Zważywszy, iż w myśl art. 111 k.s.h. komandytariusz odpowiada do wysokości sumy komandytowej za zobowiązania spółki wobec jej wierzycieli, wierzyciele powinni wiedzieć, kto w spółce wobec nich odpowiada bez ograniczeń. W istotę spółki komandytowej wpisany jest dychotomiczny podział ról pomiędzy jej wspólnikami, to znaczy rolę aktywną pełni komplementariusz, a pasywną komandytariusz. Ten pierwszy reprezentuje oraz prowadzi sprawy spółki, drugi zaś wnosi do niej określony w umowie kapitał. Przyjmuje się zatem, że skoro to przede wszystkim na komplementariuszach ciążą obowiązki oraz ryzyka związane z funkcjonowaniem spółki, powinni oni być każdorazowo ujawnieni w firmie spółki komandytowej. $Z$ wymienionych powodów nie może ona zawierać nazwiska komandytariusza, gdyż jego rola w spółce z zasady podlega daleko idącym ograniczeniom. Przyjęcie stanowiska przeciwnego wiązałoby się z wprowadzeniem osób trzecich w błąd ${ }^{5}$.

Artykuł 104 § 4 k.s.h. składa się z dwóch różnych norm. W zdaniu pierwszym zakazuje on umieszczenia nazwiska komandytariusza w firmie spółki komandytowej. W drugim zaś określa sankcje za naruszenie normy wynikającej ze zdania poprzedniego. Obydwa te aspekty zostaną poddane analizie w świetle tytułowej problematyki.

\section{Zakres przedmiotowy pośredniego umieszczenia nazwiska komandytariusza w firmie sp. $k$.}

W tym miejscu konieczne staje się nakreślenie zakresu przedmiotowego pośredniego umieszczenia nazwiska komandytariusza w firmie spółki komandytowej. Zasadniczo, przypadek ten nie może znaleźć zastosowania w odniesieniu do osób fizycznych, gdyż zgodnie z art. $43^{4}$ kodeksu cywilnego ${ }^{6}$ firmą osoby

4 T. Siemiątkowski, op. cit., art. 104, pkt 7.

5 Zob. T. Szczurkowski, op. cit., s. 373; A. Szumański, [w:] System Prawa Prywatnego, t. 16. Prawo spótek osobowych, red. A. Szajkowski, Warszawa 2016, s. 1180-1181.

${ }^{6}$ Ustawa z dnia 23 kwietnia 1964 roku — Kodeks cywilny (tekst jedn. Dz.U. z 1964 r. Nr 16, poz. 93 ze zm.), dalej: k.c. 
fizycznej jest jej imię i nazwisko, a zatem gdy w spółce występuje komplementariusz o takim samym nazwisku jak komandytariusz, nie zachodzi przypadek pośredniego umieszczenia nazwiska komandytariusza w firmie spółki, a umieszczenia nazwiska identycznego. Wiąże się to z problemami odróżnienia różnych wspólników, których łączy wspólne nazwisko (przeważnie ta rzecz dotyczy spółek rodzinnych ${ }^{7}$, a nie w istocie tej samej osoby. Przypadek pośredniego umieszczenia nazwiska komandytariusza w firmie spółki zachodzi więc tylko wtedy, gdy komplementariuszem spółki jest osoba prawna lub inna jednostka organizacyjna ${ }^{8}$.

W praktyce obrotu najczęściej problem ten dotyczy spółek komandytowych, których komplementariuszem jest spółka z ograniczoną odpowiedzialnością, a komandytariuszem lub komandytariuszami są wspólnicy komplementariusza. Zarazem w firmie spółki z ograniczoną odpowiedzialnością pojawia się nazwisko komandytariusza spółki komandytowej. W najprostszej konfiguracji mowa jest o następującym przypadku:

korpus sp. z o.o. zawierający nazwisko komandytariusza sp. k. — przykładowo:

Kowalski Produkcja Mebli Spótka z Ograniczona Odpowiedzialnościa Spótka Komandytowa

Komplementariusz: Kowalski Produkcja Mebli Spółka z Ograniczoną Odpowiedzialnościa, której wspólnikiem jest Jan Kowalski

Komandytariusz: Jan Kowalski

Analogiczne rozwiązania mogą dotyczyć sytuacji, gdy komandytariuszem jest osoba prawna lub jednostka organizacyjna będąca zarazem wspólnikiem komplementariusza, której to nazwa widnieje w firmie komplementariusza. Zachodzi tutaj przypadek wieloszczeblowego pośredniego umieszczenia nazwiska komandytariusza w firmie spółki komandytowej. W tym wypadku należy jednak podkreślić, iż firma komandytariusza takiej spółki musi być w całości umieszczona w firmie komplementariusza, gdyż jej skrócenie nie jest już równoznaczne z jej inkorporacją do firmy komplementariusza, a po prostu z przyjęciem innej (nawet jeśli zbliżonej) firmy. Zastrzeżenie to oczywiście nie ma zastosowania do przypadku, gdy firma owego komplementariusza rozszerza firmę przywołanego komandytariusza. Ponadto, w doktrynie nie kwestionuje się tezy, iż brakuje podstaw do różnicowania wykładni art. 104 § 4, w zależności od tego, czy odnosi się on do

${ }^{7} \mathrm{~W}$ tej sferze istnieją dwie przeciwstawne interpretacje nakazujące przypadki dwuznaczne interpretować: na korzyść komandytariusza, uznając, iż to nie jego nazwisko jest umieszczone, por. M. Spyra, op. cit., s. 334-335; T. Siemiątkowski, op. cit., art. 104, pkt 44; lub przeciwnie (pogląd rygorystyczny): T. Szczurkowski, op. cit., s. 373-374.

8 W literaturze dominuje pogląd, iż komplementariuszem spółki komandytowej może być nie tylko dowolna osoba prawna, ale też inne jednostki organizacyjne; por. P. Pinior, op. cit., s. 178 (i przywołana tam literatura). Głosy przeciwne: A. Herbet, Spółka komandytowa wedtug kodeksu spótek handlowych. Komentarz, Lublin 2004, s. 50. 
nazwiska, czy też do firmy (nazwy) komandytariusza ${ }^{9}$, zatem dalej, dla uproszczenia wywodu, mowa jest wyłącznie o nazwisku komandytariusza.

Poboczne uwagi należy poczynić także w kontekście nazwisk wieloczłonowych. Jeśli komandytariusz posługuje się nazwiskiem składającym się z co najmniej dwóch członów, wskazane jest uznanie, iż problematyka pośredniego umieszczenia nazwiska komandytariusza w firmie spółki odnosi się do nich tylko wtedy, gdy jej firma zawiera wszystkie owe człony. W przeciwnym wypadku należy je klasyfikować jako nazwiska odrębnych podmiotów.

\section{Wykładnia zakazu określonego w art. 104 § 4 zd. 1 k.s.h. w kontekście pośredniego umieszczenia nazwiska komandytariusza $w$ firmie $\mathrm{sp}$. $\mathrm{k}$.}

\subsection{Uwagi ogólne}

Art. $104 \S 4$ zd. 1 k.s.h. stanowi, że nazwisko komandytariusza nie może zostać umieszczone w firmie spółki. Norma ta została precyzyjnie skonstruowana oraz nie przewiduje żadnych wyjątków w jakichkolwiek przepisach odnoszących się do uregulowania funkcjonowania spółki komandytowej. Tylko pozornie norma ta pozostaje spójna z pozostałymi przepisami odnoszącymi się do firmy spółki komandytowej. W kontekście analizowanego w niniejszym artykule zagadnienia zasadniczo dochodzi do konfliktu tej normy z normą zawartą w art. $104 \S 3$ zd. 1 k.s.h., przewidującą, iż jeśli komplementariuszem jest osoba prawna, firma spółki komandytowej musi zawierać pełne brzmienie firmy tej osoby prawnej z oznaczeniem ,spółka komandytowa”.

W poprzednim rozdziale posłużono się przykładem spółki Kowalski Produkcja Mebli Spótka z Ograniczona Odpowiedzialnością. Zgodnie z art. 104 § zd. 1 k.s.h., jeśli podmiot ten ma zostać komplementariuszem w spółce komandytowej, jego firma $\mathrm{w}$ istocie musi zostać inkorporowana do firmy spółki komandytowej ${ }^{10}$. Przepis ten zasadniczo nie powinien wywoływać żadnych wątpliwości, wymaga bowiem posłużenia się pełnym brzmieniem firmy osoby prawnej, nie dopuszczając wprowadzenia w niej jakichkolwiek modyfikacji, a w szczególności jej skrócenia bądź wydłużenia, gdyż pozostawałoby to sprzeczne z treścią tego przepisu. Jeśli posłużyć się przywołanym wcześniej przykładem, oznacza to, iż ów Kowalski — komandytariusz zostanie ujawniony w firmie spółki komandytowej na mocy przepisów k.s.h., a więc zasadniczo wbrew własnej woli. Istota problematyki pośredniego umieszczenia nazwiska komandytariusza w firmie spółki komandy-

9 Por. przykładowo: M. Spyra, op. cit., s. 335-336; A. Gawrysiak-Zabłocka, Firma osobowych spótek handlowych - uwagi de lege ferenda, [w:] M. Stec, T. Mróz, Instytucje prawa handlowego w przyszlym kodeksie cywilnym, Warszawa 2012, s. 645; P. Pinior, op. cit., s. 179; T. Siemiątkowski, op. cit., art. 104, pkt 5.

10 M. Spyra, op. cit., s. 332-333. 
towej zatem sprowadza się do tego, że jego nazwisko zostało w niej umieszczone nie dlatego, iż przykładowo taka była wola komandytariusza, czy też nie dochował on należytej ostrożności przy konstruowaniu firmy spółki, ale ponieważ postąpił zgodnie z normą (o charakterze ius cogens) z art. $104 \S 3$ k.s.h., określającą poprawną metodę konstruowania firmy spółki komandytowej z komplementariuszem będącym osobą prawną. Zachodzi tutaj oczywisty konflikt przepisów ustawowych, który prowadzi do pokrzywdzenia komandytariusza postępującego zgodnie z przepisami prawa.

Jeśli poddać art. $104 \S 4$ zd. 1 k.s.h. tylko i wyłącznie wykładni literalnej, to nie pozostawia ona żadnych wątpliwości, że zawsze zakazane jest zamieszczanie w firmie spółki nazwiska komandytariusza. W tym ujęciu zakaz ten siłą rzeczy obejmuje przypadek pośredniego umieszczenia nazwiska komandytariusza w firmie spółki komandytowej, gdyż nazwisko komandytariusza będące częścią firmy innego podmiotu nadal pozostaje jego nazwiskiem. Dochodzi zatem do jego umieszczenia, co musi skutkować sankcją ze zdania 2 tego przepisu. Podejście to wydaje się jednak nazbyt restrykcyjne, wykracza poza cel tej regulacji oraz w zbyt dużym stopniu ogranicza możliwości konstruowania firmy spółki komandytowej, szczególnie ze względu na nakaz wypływający z art. $104 \S 3$ zd. 1 k.s.h. Wykładni literalnej można przeciwstawić wykładnię funkcjonalną, o mniej rygorystycznym podejściu, która opiera się na przeprowadzeniu analizy, czy tak skonstruowana firma wypełnia podstawową dyrektywę art. $43^{2} \S 2$ k.c., nakazującą, by firma nie wprowadzała osób trzecich w błąd ${ }^{11}$. Konsekwencje płynące z przyjęcia każdego z tych modeli wykładniczych art. $104 \S 4$ zd. 1 k.s.h. zostały zaprezentowane w dalszej części niniejszej pracy.

\subsection{Art. $104 \S 4$ zd. 1 k.s.h. w świetle wykładni literalnej}

W ujęciu zasad wykładniczych prymat przyznawany jest wykładni literalnej. Jednakże dopuszczalne jest zastosowanie innych metod wykładniczych przepisów dopiero wtedy, gdy rezultaty wypływające z wykładni literalnej nie przynoszą pożądanych rezultatów, dlatego niniejsze rozważania w pierwszej kolejności poddają omawianą problematykę tej metodzie wykładniczej.

Art. $104 \S 4$ zd. 1 k.s.h. należy interpretować ściśle i bez wyjątków, jako że ustawa takich nie przewiduje. Ilekroć nazwisko komandytariusza zostanie w firmie spółki umieszczone, tylekroć zostaje spełniona dyspozycja tej normy, a tym samym skutkuje to konsekwencjami wynikającymi ze zd. 2 omawianego przepisu. Przepis ten przeważa nad postanowieniami art. $104 \S 3$ zd. 1 k.s.h., gdyż nakaz zawarty w tym przepisie w żaden, wprost w ustawie przewidziany, sposób nie jest traktowany jako przesłanka łagodząca sankcję z tytułu umieszczenia nazwiska komandytariusza w firmie spółki.

11 Klasyfikacja przyjęta za: P. Pinior, op. cit., s. 180. 
Tak przyjęte rozumowanie ma następujące konsekwencje. Po pierwsze, nawet jeśli umieszczenie nazwiska komandytariusza w firmie spółki komandytowej wynika z wymogów ustawowych, ze względu na ochronę bezpieczeństwa obrotu oraz interesów wierzycieli spółki należy przyjąć, iż komandytariusz ten odpowiada w pełnej wysokości za zobowiązania spółki wobec jej wierzycieli. Ma on bowiem wpływ na kształtowanie stosunku spółki, w tym także firmy spółki będącej komplementariuszem, którą mógłby ukształtować w taki sposób, by nie zawierała jego nazwiska. Pozbawienie go ochrony jest także w znacznej mierze uzasadnione tym, iż pośrednio komandytariusz staje się komplementariuszem spółki komandytowej, jako że jest podmiotem bądź jednym z podmiotów konstytuujących podmiot, będącym komplementariuszem. Oznacza to, iż z jednej strony ogranicza on swoją odpowiedzialność poprzez przyjęcie roli komandytariusza w spółce komandytowej wobec jej wierzycieli, z drugiej zaś firmuje jej działalność swoim nazwiskiem poprzez inny podmiot, co w świetle art. $43^{2} \S 2$ k.c. może wprowadzać osoby trzecie w błąd co do tego, kto faktycznie kryje się pod daną firmą. Z perspektywy przeciętnego obywatela konstrukcja firmy: [nazwisko] sp. z o.o. sp. k. może być traktowana nie tyle jako spółka komandytowa o bardziej złożonej strukturze wspólników, ile po prostu spółka, pod postacią której Kowalski prowadzi swoje przedsiębiorstwo, choć z perspektywy czysto prawnej rolę tę pełni owa spółka $\mathrm{z}$ ograniczoną odpowiedzialnością jako komplementariusz. Nie jest także jasne, gdyż w żaden sposób nie wynika to $\mathrm{z}$ analizy treści samej firmy spółki komandytowej, która konkretna część jej korpusu odnosi się do przykładowej sp. z o.o. (poza samym oznaczeniem tej formy spółki oraz ostatnim słowem przed nim figurującym ${ }^{12}$ ), a która już nie. Czy bowiem nazwisko widniejące przed oznaczeniem korpusu „sp. z o.o.” jest częścią firmy tej ostatniej, czy też już dodatkiem do firmy spółki komandytowej? Czy pochodzi ono od innego komplementariusza tej spółki, czy też nie? Wątpliwości nie budzą tylko dwa przypadki: gdy firma spółki komandytowej brzmi następująco: Kowalski sp. z o.o. sp. k., tj. firma jej komplementariusza zawiera tylko jedno słowo w swym korpusie, oraz gdy nazwisko jest umieszczone w firmie spółki komandytowej po oznaczeniu formy prawnej komplementariusza (korpus sp. z o.o. Kowalski sp. k.). Artykuł $104 \S 3$ zd. 1 k.s.h. w żaden sposób nie określa bowiem, w którym miejscu firmy spółki zamieszczony miałby być dodatek do niej. Tym samym można polemizować z poglądem wyrażonym w literaturze ${ }^{13}$, iż dodatek wskazujący na formę prawną rozwiewa wątpliwości w kontekście wykładni art. $104 \S 4$ zd. 1 k.s.h.

Po drugie, w świetle przyjęcia wykładni literalnej konieczne staje się bardziej ostrożne budowanie firmy spółki komandytowej, której komplementariuszem jest osoba prawna. Chociaż zgodnie z art. $104 \S 3 \mathrm{w}$ związku z art. $104 \S 1$ k.s.h. dopuszczalne jest rozbudowanie korpusu o dodatkowe określenia, szczególnie pod

\footnotetext{
12 Korpus firmy bowiem musi składać się przynajmniej z jednego słowa.

13 A.J. Witosz, op. cit., s. 698.
} 
postacią imienia, nadal nie rozwiązuje to problemu pośredniego umieszczenia nazwiska komandytariusza w firmie spółki, gdyż nie jest jasne, czy ów dodatek odnosi się do spółki komandytowej, czy do inkorporowanej firmy osoby prawnej ${ }^{14}$. Wymusza to zatem działania, które mogą być poczytywane za utrudniające prowadzenie działalności gospodarczej pod postacią uprzedniej zmiany firmy osoby prawnej mającej zostać komplementariuszem spółki komandy towej w taki sposób, aby usunąć z niej nazwisko przyszłego komandytariusza.

Po trzecie, przyjęcie bardziej rygorystycznego stanowiska jest pożądane z perspektywy wymogów pewności obrotu. Klasyfikacja przypadku pośredniego umieszczenia nazwiska komandytariusza spółki komandytowej w jej firmie jako automatycznego naruszenia art. $104 \S 4$ zd. 1 k.s.h. usuwa wszelkie wątpliwości w tej materii oraz przyczynia się do ujednolicenia zasad interpretacji naruszeń prawa firmowego w tym przypadku.

\subsection{Art. 104 § $4 \mathrm{zd} .1$ k.s.h. w świetle wykładni funkcjonalnej}

Ze względu na zachodzącą oczywistą kolizję zakazu określonego w art. 104 § 4 zd. 1 k.s.h. oraz nakazu wynikającego z art. $104 \S 3$ zd. 1 k.s.h. może być zasadne odejście od wykładni literalnej tego przepisu na rzecz wykładni funkcjonalnej uwzględniającej inne rozłożenie akcentów w obrębie celów tego przepisu oraz potrzeby obrotu.

W pierwszej kolejności należy wskazać, iż bezzasadne jest przyjmowanie, że zastosowanie się założycieli spółki do dyspozycji art. $104 \S 3 \mathrm{zd} 1$ k.s.h. ex lege musi wiązać się z penalizacją komandytariusza w sytuacji, gdy firma osoby prawnej zawiera nazwisko komandytariusza. Celem tego przepisu jest ochrona uczestników obrotu oraz kontrahentów spółki w ten sposób, by poprzez ujawnienie w firmie nazwiska komandytariusza nie dochodziło do zatarcia różnicy między komplementariuszami a komandytariuszami w spółce ze względu na odmienne pełnione przez nich role. Komplementariuszem owej spółki nie jest bowiem komandytariusz, lecz określona osoba prawna. Wprost wskazuje na to firma komplementariusza wyróżniająca się w firmie spółki komandytowej, co przeciętny obywatel powinien z łatwością zauważyć. Ze względu na przyjętą konstrukcję osób prawnych w polskim porządku prawnym nie można wysuwać wniosku, iż dochodzi do całkowitego zatarcia granicy osobowości prawnej pomiędzy nimi a ich członkami, nawet jeśli w nazwach tych podmiotów figurują nazwiska bądź inne określenia wprost odnoszące się do ich członków. Ponadto, w razie wątpliwości co do tego, kto w spółce komandytowej jest komplementariuszem, a kto komandytariuszem, możliwe jest sprawdzenie tych faktów poprzez zbadanie

14 Por. „Kowalski Produkcja spółka z ograniczoną odpowiedzialnością sp. k.” z „Jan Kowalski Produkcja spółka z ograniczoną odpowiedzialnością sp. k.”, gdy komandytariusz ma na imię Stefan, a Jan to jego brat przyjmujący rolę drugiego komplementariusza w spółce, który na mocy art. $104 \S 3$ zd. 2 k.s.h. zostaje w firmie spółki ujawniony. 
wyciągu z Krajowego Rejestru Sądowego. Powątpiewać zatem należy, czy tak określona firma spółki komandytowej wprowadza w błąd inne podmioty obrotu gospodarczego, od których przeważnie wymaga się zachowania określonego poziomu staranności przyjętego w obrocie.

Zaprezentowane wnioski łączą się także z konstatacją, iż podstawowym problemem wymagającym rozwiązania w niniejszej kwestii jest to, czy zgodne z prawem zachowanie się określonego podmiotu powinno automatycznie podlegać sankcjom wynikającym z innej normy prawnej, która zasadniczo nie jest z nią powiązana. Negatywne skutki wynikające z zastosowania się przez podmioty prawa prywatnego do błędnie skonstruowanych przepisów prawa przez ustawodawcę nie powinny ich obciążać. Konieczne jest zatem przyjęcie, iż art. $104 \S 3$ zd. 1 k.s.h. jest normą wyższego rzędu w stosunku do art. $104 \S 4$ zd. 1 k.s.h, a zatem zastosowanie się do tej pierwszej zwalnia z odpowiedzialności przewidzianej za naruszenie tej drugiej. Artykuł $104 \S 4$ k.s.h. jako przepis przewidujący rozszerzenie odpowiedzialności komandytariusza wobec osób trzecich nie powinien być interpretowany rozszerzająco, tj. tak, jak na gruncie wykładni literalnej, a zawężająco, tj. tylko do przypadków, gdy w sposób oczywisty umieszczone zostaje nazwisko komandytariusza spółki komandytowej w jej firmie. Bezdyskusyjnym przypadkiem umieszczenia takiego nazwiska może być tylko sytuacja, gdy w gronie komplementariuszy żadna osoba fizyczna nie nosi takiego samego nazwiska, a nazwisko komandytariusza zostaje umieszczone w firmie. Zarazem należy pamiętać, iż w tym wypadku nie można stawiać znaku równości pomiędzy nazwiskiem a firmą osoby prawnej lub innej jednostki organizacyjnej, przez co te dwie ostatnie kategorie podmiotów należy wyłączyć z omawianej problematyki ze względu na art. $104 \S 3$ zd. 1 k.s.h.

\subsection{Wnioski}

Na podstawie poczynionych rozważań wskazane jest przychylenie się do wykładni funkcjonalnej z kilku powodów. Po pierwsze, przepisy rozszerzające odpowiedzialność komandytariusza za zobowiązania spółki komandytowej powinno się interpretować w sposób zawężający. Po drugie, w razie wystąpienia wątpliwości co do stosowania przepisów prawa, gdy zachodzi możliwość pociągnięcia do odpowiedzialności podmiotu postępującego zgodnie z prawem, wątpliwości te należy rozstrzygać na jego korzyść. Po trzecie, przesadny rygoryzm formalny w zakresie konstruowania firm spółek komandytowych przyczyniłby się do utrudnienia ich funkcjonowanie $\mathrm{w}$ obrocie, a tym samym rzutowałby na ograniczenie ich zastosowania.

Finalnie, odnosząc się do kwestii dopuszczalności zarejestrowania przez sąd rejestrowy spółki komandytowej z firmą, w której pośrednio umieszczono nazwisko jej komandytariusza oraz konsekwencji z tego wypływających należy stwierdzić, co następuje. Poza niniejszym artykułem leży kwestia przecięcia sporu, czy ge- 
neralne naruszenie normy w art. $104 \S 4$ zd. 1 k.s.h. powinno skutkować obligatoryjną odmową rejestracji danej spółki komandytowej przez sąd rejestrowy, czy nie. A zatem, czy sankcja ze zdania drugiego tego przepisu dotyczy wyłącznie sytuacji, w której komandytariusz świadomie i dobrowolnie naruszył zakaz, czy też sankcja powinna być zastosowana tylko w razie omyłki dokonanej przez sąd rejestrowy, który bezzasadnie zarejestrował spółkę komandytową z firmą sformułowaną w sposób niezgodny z przepisami prawa ${ }^{15}$. W oparciu o zajęte $\mathrm{w}$ dotychczasowych rozważaniach stanowisko dotyczące pośredniego umieszczenia nazwiska komandytariusza w firmie spółki przyjęto, iż nie narusza ono zakazu określonego w art. $104 \S 4$ zd. 1 k.s.h., a zatem nie skutkuje traktowaniem komandytariusza $\mathrm{w}$ sferze odpowiedzialności za zobowiązania spółki niczym jej komplementariusza. Zarazem sąd rejestrowy nie ma podstaw do odmowy zarejestrowania tak skonstruowanej firmy spółki komandytowej.

\section{Zakończenie}

Zarysowana w niniejszym artykule problematyka pośredniego umieszczenia nazwiska komandytariusza w firmie spółki komandytowej tylko pozornie nie budzi wątpliwości. Z racji niespójnej konstrukcji przepisów art. $104 \S 3$ zd. 1 k.s.h. oraz art. $104 \S 4$ zd. 1 k.s.h. konieczne było wyprowadzenie reguł interpretacyjnych mających na celu rozwianie wątpliwości, jak należy klasyfikować przypadki mające miejsce w praktyce obrotu gospodarczego w świetle przepisu art. 104 $\S 4$ k.s.h.

W oparciu o dokonane zestawienie różnych modeli wykładniczych przytoczonych przepisów, tj. wykładni zarówno literalnej, jak i funkcjonalnej, wykazano, iż przypadek pośredniego umieszczenia nazwiska komandytariusza w firmie spółki powinno się traktować liberalnie, odchodząc od przesadnego rygoryzmu formalnego na rzecz potrzeb praktyki obrotu.

\section{Bibliografia}

Hajdys P., Firma spółki osobowej - uwagi de lege lata i postulaty de lege ferenda, PPH 2012, nr 10. Herbet A., Spótka komandytowa wedtug kodeksu spótek handlowych. Komentarz, Lublin 2004.

Kodeks spótek handlowych. Komentarz, red. J. Bieniak, M. Bieniak, G. Nita-Jagielski, K. Oplustil,

R. Pabis, A. Rachwał, M. Spyra, G. Suliński, M. Tofel, R. Zawłocki, Warszawa 2017.

Kodeks spótek handlowych. Komentarz, red. Z. Jara, Warszawa 2017.

Kodeks spótek handlowych. Komentarz, red. J.A. Strzępka, Warszawa 2012.

Kodeks spótek handlowych. Komentarz. Tytut I. Przepisy ogólne. Tytut II. Spótki osobowe, t. 1, red.

R. Potrzeszcz, T. Siemiątkowski, LEX/el. 2010.

Kodeks spótek handlowych, t. 1. Komentarz do art. 1-150, red. A. Kidyba, Warszawa 2017.

15 Por. poglądy liberalne w tej kwestii: T. Szczurkowski, op. cit., s. 374 i przywołana tam literatura, oraz poglądy o rygorystycznym podejściu co do roli sądu rejestrowego: P. Pinior, op. cit., s. 179 i przywołana tam literatura. 
Kodeks spółek handlowych, t. 1. Przepisy ogólne. Spótki osobowe. Komentarz do artykułów 1-150, red. S. Sołtysiński, A. Szajkowski, A. Szumański, J. Szwaja, Warszawa 2012.

Rodzynkiewicz M., Kodeks spółek handlowych. Komentarz, Warszawa 2012.

Stec M., Mróz T., Instytucje prawa handlowego w przyszłym kodeksie cywilnym, Warszawa 2012. System Prawa Prywatnego, t. 16. Prawo spółek osobowych, red. A. Szajkowski, Warszawa 2016.

\section{The indirect placement of a limited partner's surname in business name of a limited liability partnership}

Summary

The issue of the indirect placement of a limited partner's surname in business name of a limited liability partnership presented in this article only at the first glance does not raise any doubts. Due to the incoherent construction of provision art. $104 \S 3$ and art. $104 \S 4$ of Polish Code of Commercial Companies, it is necessary to introduce interpretational rules concerning classification of such cases occurring in the business practice.

Because of remarks made in this article, it was proved that the case of the indirect placement of a limited partner's surname in business name of a limited liability partnership should be liberally treated, therefore the needs of business practice shall be respected rather than strict interpretation of legal provisions. 